https://doi.org/10.35339/msz.2019.82.01.05

УДК 616-002-036.12:616-056.52:616.379-008.64:616.1

B.В. Рябуха

ДУ «Національний інститут терапї ім. Л.Т. Малої НАМН Украӥни», м. Харків

\title{
ХРОНІЧНЕ ЗАПАЛЕННЯ, АСОЦІЙОВАНЕ 3 ОЖИРІННЯМ, ЦУКРОВИМ ДІАБЕТОМ 2-ГО ТИПУ \\ ТА КАРДІОВАСКУЛЯРНИМ РИЗИКОМ, ЯК МІШЕНЬ ДЛЯ ТЕРАПЕВТИЧНИХ ВТРУЧАНЬ. \\ ЧАСТИНА 2
}

\begin{abstract}
Огляд літератури присвячено актуальній дослідницькій проблемі - хронічному запаленню, асоційованому з ожирінням, цукровим діабетом 2-го типу та кардіоваскулярним ризиком. Оскільки запалення виступає в ролі патологічного медіатору за цих коморбідних станів, робляться спроби вплинути на хронічний запальний процес за допомогою лікарських засобів для зниження ризику виникнення серцево-судинних захворювань атеросклеротичного генезу. Це пов'язано з патогенетичними сигнальними механізмами, що ініціюють і підтримують запалення, а також залучають його в розвиток інсулінорезистентності й атерогенез. Розглянуто способи фармакологічного втручання з безпосереднім впливом на запалення (саліцилати, низькодозове застосування метотрексату, біологічні препарати з протизапальною дією) та інші лікувальні заходи з протизапальним ефектом (антилейкотрієнова терапія) у контексті їхнього впливу на кардіометаболічний ризик.

Ключові слова: кардіометаболічні розлади, запалення, лікарські засоби.
\end{abstract}

Хронічне запалення, пов'язане з ожирінням, спричинює розвиток багатьох метаболічних захворювань, таких як цукровий діабет 2-го типу, неалкогольна жирова хвороба печінки та атеросклероз. У зв'язку з цим терапевтичні засоби, які прямо або опосередковано впливають на цей стан, перебувають на передньому краї досліджень ожиріння. У першій частині цього огляду було розглянуто зміни способу життя, статини та цукрознижуючі препарати з протизапальними властивостями [1]. Мета даної роботи - розглянути терапевтичні стратегії з безпосереднім впливом на запалення.

\section{3. Фармакологічні втручання}

\section{1. Саліцилати}

Ацетилсаліцилова кислота (аспірин), як відомо, незворотно пригнічує циклооксигеназу тромбоцитів та ендотеліальних клітин, знижуючи, таким чином, утворення тромбоксану $\mathrm{A}_{2}$, а в разі застосування великих доз - $\mathrm{i}$ простацикліну. Низькі добові дози аспірину використовують для запобігання тромбоутворенню в заходах первинної і вторинної профілактики кардіоваскулярних подій. Протизапальні й метаболічні ефекти саліцилатів відрізняються від дії інших представників класу нестероїдних протизапальних засобів. Високі добові дози саліцилатів застосовують у лікуванні хворих за суглобового болю завдяки пригніченню нуклеарних транскрипційних факторів IKK $\beta$ i NF-kb. Першу спробу використання саліцилатів для зниження глікемії при лікуванні хворих на цукровий діабет було зроблено ще в 1876 році. Понад 10 років тому в сучасних дослідженнях використано димер саліцилатів -

(C) B.В. Рябуха, 2019 
салсалат, який відноситься до сімейства проліків. Установлено, що ця лікарська речовина знижує рівні глюкози і тригліцеридів натще, підвищує вміст у крові адипонектину та покращує утилізацію глюкози тканинами під час проведення еуглікемічного гіперінсулінемічного клемп-тесту пацієнтам із цукровим діабетом 2-го типу або з ожирінням без діабету. При вивченні протизапальної дії салсалату встановлено його здатність знижувати вміст лейкоцитів периферичної крові й майже не змінювати концентрацію С-реактивного білка. Толерантність до салсалату була задовільною, але в окремих осіб спостерігалось підвищення сироваткового вмісту холестерину ліпопротеїдів низької щільності і транзиторне збільшення рівнів сечового альбуміну. I хоча салсалат ефективно знижує концентрацію глюкози в крові, його вплив на атерогенез залишається незрозумілим. Салсалат знижує активність транскрипційного нуклеарного фактора NF-kb ендотеліальних клітин і покращує функцію ендотелію вже через 4 дні використання в осіб 3 надлишковою масою тіла. Однак при дозі 3,5 г/добу вплив на ендотелій-залежну вазодилатацію був відсутнім, а доза 4,5 г/добу опинилася інтолерантною. Залишається не3'ясованим, чи є відсутність вазодилатації плечової артерії дозозалежною, чи може 3 якихось причин не зберігається короткотерміновий початковий вазодилатуючий ефект або вазодилатації перешкоджає сумарний вплив додаткових факторів [2].

Цікавими є результати вивчення впливу салсалату на прогресування некальцинованих атеросклеротичних бляшок у коронарних артеріях. Сто дев'яносто осіб із надлишковою масою тіла й ожирінням із документованою ішемічною хворобою серця і статинотерапією було рандомно розподілено на групу хворих, що отримували салсалат (3,5 г/добу), і групу плацебо та проведено мультидетекторну комп'ютерну томографію коронарних артерій через 30 місяців лікування. Прогресування атеросклерозу в некальцинованих бляшках коронарних артерій хворих обох груп за таким показником, як об'єм бляшки, не виявлено. Однак із позицій ефективної багатофакторної профілактики вагомим результатом було те, що в групі плацебо не спостерігалось прогресування коронарного атеросклерозу [3].
Щодо молекулярного механізму дії саліцилатів, то останні пригнічують $\beta$-одиницю IK-kb кінази i власне нуклеарний транскрипційний фактор NF-kb, не зв'язуючись безпосередньо з IKK $\beta$ або іншими компонентами NF-kb комплексу. Відомо, що саліцилати активують АМФ-індуковану протеїнкіназу (АМФПК), сполучаючись з їі $\beta 1$-субодиницею, яка відповідає за покращання метаболічних показників. Припускається, що певний позитивний внесок у покращання метаболічного профілю робить зменшення кліренсу інсуліну [4]. Активація АМФПК чітко супроводжується пригніченням транскрипційного нуклеарного фактора NF-kb, хоча тонкі молекулярні механізми приєднання АМФПК до IKK та NF-kb досі не встановлено. Оскільки саліцилати активують АМФПК, не обов'язково вважати пригнічення нуклеарного фактора NF-kb відповідальним за покращання метаболічного статусу пацієнта [5].

\section{2. Низькодозове застосування мето-} трексату

Метотрексат широко використовується в невеликих добових дозах у лікуванні хворих на ревматичні і псоріатичні артрити та інші патологічні стани. Крім того, у клінічних дослідженнях вивчають його вплив на метаболічні показники за цукрового діабету 2-го типу та серцево-судинних захворювань атеросклеротичного генезу. Доклінічну обгрунтованість такого підходу доведено за результатами експериментальних досліджень у галузі клітинної біології та in vivo. Установлено, що метотрексат пригнічує активність ферменту, що перетворює клітинний аміноімідазол кокарбоксамідорибонуклеат (АІКРН) у 5-аміноімідазол-4-карбоксамід-1- $\beta$-D-рибофуранозил5'-монофосфат. Дана обставина призводить до внутрішньоклітинного накопичення АІКРН, наслідками якого можуть бути локальне вивільнення аденозину, активація аденозинового сигнального механізму або клітинна автономна активація АМФПК. Потенційне покращання кардіометаболічного статусу, індуковане активацією аденозинового рецептора, може опосередковуватись зниженням адгезії лейкоцитів на судинному ендотелії внаслідок пригнічення активності селектину й інтегрину через зменшення продукції радикалів кисню або інших негативних чинників стимульованими нейтрофілами чи активованими макро- 
фагами. На моделях експериментальних тварин виявлено здатність аденозину стимулювати регенерацію панкреатичних $\beta$-клітин. 3 другого боку, внутрішньоклітинне накопичення АІКРН безпосередньо активує АМФПК. За цим механізмом метотрексат стимулює поглинання глюкози й окиснення ліпідів скелетними м'язами, що призводить до зниження рівня глікемії й ліпідемії у гризунів з експериментально відтвореним цукровим діабетом 2-го типу. У кроликів з аліментарною гіперхолестеринемією продемонстровано здатність метотрексату пригнічувати атерогенез. Активація АМФПК безпосередньо чинить протизапальну дію і супроводжується пригніченням нуклеарного транскрипційного фактора NF-kb [6]. У одному з малих когортних досліджень отримано дані, які свідчать про зниження глікемії під впливом метотрексату [7]. Триває дослідження the Cardiovascular Inflammation Reduction Trial, метою якого є оцінити безпечність й ефективність метотрексату як лікарського засобу 3 цільовим впливом на запалення для зниження частоти несприятливих великих кардіоваскулярних подій у пацієнтів із метаболічним синдромом і документованою ішемічною хворобою серця. Крім того, у цьому дослідженні передбачається оцінити вплив низькодозового застосування метотрексату на показники метаболічного профілю пацієнтів.

\section{3. Біологічні препарати 3 протиза- пальною дісю}

\subsection{1. Інгібітори ФНП- $\alpha$}

Участь ФНП- $\alpha$ в патофізіології інсулінорезистентності встановлено в експериментальних дослідженнях і не підтверджено в клінічних. Однак застосування антагоністів ФНП- $\alpha$ в лікуванні пацієнтів із ревматоїдним і псоріатичним артритами, хворобою Крона асоціюється зі зниженням глікемії й частоти випадків діабету. Оскільки ці дослідження не були рандомізованими і в більшості не були проспективними, тлумачення їх слід проводити з обережністю. Дослідження з антагоністами ФНП- $\alpha$ в осіб з кардіометаболічними розладами (КМР) були малочисельними й нетривалими. За протизапальних ефектів покращання чутливості тканин до інсуліну або зниження глікемії не виявлялось унаслідок недостатньої тривалості дослідження або спроможності виявити ці зміни. Лише в 6-місячному дослідженні пригнічення ФПН- $\alpha$ супроводжу- валося зниженням глікемії натще й підвищенням концентрації адипонектину в крові в осіб із ожирінням без цукрового діабету [5].

\subsection{2. Антагоністи ІЛ-1及}

Існують 11 представників сімейства IЛ-1, однак до КМР найбільш причетним є ІЛ-1 $\beta$ сигнальний механізм, який реалізується через IЛ-1 рецептор 1-го типу (IЛ-1R1), а пригнічення ІЛ-1 сигнального механізму відбувається завдяки впливу ендогенного антагоніста IЛ-1Ra, який тільки конкурентно сполучається, а не активує IJ-1R1. Активація транскрипційного нуклеарного фактора NF-kb через IЛ-1R1 peцептор опосередковується MyD88 і запускає каскад медіаторів і процесів, зокрема $\mathrm{NOS}$, ендотелін-1, ендотеліальну гладеньком'язову проліферацію, активацію макрофагів і молекул адгезії, продукцію хемокінів і цитокінів. Багато $з$ цих складових робить внесок у виникнення цукрового діабету й атеротромбозу. Як і у випадку з ФНП- $\alpha$, аліментарний механізм ініціює гіперпродукцію ІЛ-1 $\beta$ у відповідь на активацію нуклеарного транскрипційного фактора NF-kb. Продукція активного ІЛ- $1 \beta$ залучає додаткові ланки, зокрема конверсію білка-попередника ІЛ- $1 \beta$ в ІЛ-1 $\beta$ за участі ферменту каспази-1 через активовану інфламасому NLRP3. При хронічному запаленні підвищена секреція ІЛ-1 $\beta$ активованими клітинами призводить до дисбалансу ендогенного антагоніста IЛ-1Ra [8].

У доклінічних і клінічних дослідженнях підтверджено потенційну роль ІЛ- $1 \beta$ у патогенезі цукрового 2-го типу. Покращання глікемічного контролю й секреторної функції $\beta$-клітин підшлункової залози в поєднанні зі зниженням маркерів системного запалення продемонстрували 70 пацієнтів із цукровим діабетом 2-го типу, яких рандомно розподілили на групу 3 щоденним прийманням упродовж 13 тижнів антагоніста IЛ-1R1 (препарат «Анакінра») i групу плацебо. Після припинення приймання анакінри спостереження сліпим методом тривало 39 тижнів, протягом яких зберігалось покращання секреторної функції $\beta$-клітин підшлункової залози в поєднанні зі зниженням маркерів системного запалення, що дозволило визнати ці ефекти тривалими. Зроблено припущення, що анакінра перериває замкнуте коло аутоіндукції в циклі утворення IЛ-1 і навіть покращує секреторну функцію $\beta$-клітин підшлункової залози за предіабету, а отже, може зовсім запобігти 
виникненню нових випадків цукрового діабету 2-го типу чи суттєво віддалити таке виникнення [9]. Окрім анакінри за цукрового діабету 2-го типу досліджували людські антитіла до ІЛ-1 $\beta$. В одному 3 досліджень після введення одноразової дози гевокізумабу знижувався рівень $\mathrm{Hb}_{\mathrm{Alc}}$ на 0,9 \% протягом 3 місяців [10]. Аналогічно 12-тижневі ін'єкції антитіл до ІЛ-1 $\beta$ (препарат LY2189102) сприяли зниженню рівня $\mathrm{Hb}_{\mathrm{Alc}}$ на $0,4 \%$, рівнів запальних біомаркерів у крові, рівнів постпрандіальної глікемії та глікемії натще в пацієнтів із цукровим діабетом 2-го типу. Як і в дослідженні з анакінрою, ефект впливу антагоністів рецепторів IЛ-1R1 на вуглеводний обмін $є$ довготривалим (зниження $\mathrm{Hb}_{\mathrm{Alc}}$ на 0,6 \% зберігається впродовж 24 тижнів) [11].

Сьогодні пригнічення активності ІЛ- $1 \beta$ вважають раціональним підходом до лікувальних втручань за серцево-судинних захворювань атеросклеротичного походження. Так, у доклінічних дослідженнях установлено, що тривалий вплив IЛ- $1 \beta$ на судинний ендотелій спричинює формування атеросклеротичних бляшок, у той час як за втрати активності ІЛ-1 $\beta$ зменшується кількість атеросклеротичних пошкоджень у судинному руслі. Атерома людини містить ІЛ-1 $\beta$ матричну рибонуклеїнову кислоту й протеїнкаспазу-1. Він перетворює про-ІЛ-1 $\beta$ в активну форму, що гіперсекретується в атеросклеротичній бляшці. Ще одним компонентом людської атероми є криштали холестерину, які активують NLRP3 інфламасому, а отже, i каспазу-1, що призводить до тригерної продукції ІЛ-1 $\beta$ і прозапальної відповіді. В одному з досліджень продемонстровано протизапальну дію препарату «Канакінумаб», який містить моноклональні антитіла до ІЛ- $1 \beta$ (знизив вміст у крові C-реактивного білка і ІЛ-6), та його здатність позитивно впливати на коагуляцію (знижував сироватковий вміст фібриногену) у хворих на цукровий діабет 2-го типу з високим кардіоваскулярним ризиком. Спостереження за пацієнтами впродовж 4 місяців після завершення введення препарату не виявило будь-яких змін рівнів $\mathrm{Hb}_{\mathrm{Al}}$, глюкози та інсуліну [12]. У більшому дослідженні The Canakinumab Antiinflammatory Thrombosis Outcome Study, спланованому для вивчення ефектів канакінумабу як на частоту кардіоваскулярних подій, так i на глікемію показано, що канакінумаб був ефективним засобом запобігання несприятли- вим серцевим подіям протягом у середньому 3,7 року завдяки зниженню рівня високочутливого С-реактивного білка в залежності дозавідповідь, однак не сприяв зменшенню кількості випадків діабету [12]. 3 публікацією результатів цього дослідження у клініцистів 3'явилися переконливі докази того, що пряме націлювання на запалення корисно для вторинної профілактики серцево-судинних захворювань і ця перевага не залежить від рівня холестерину. Даний факт є нагадуванням про те, що для осіб із залишковим запальним ризиком з'являються нові терапевтичні можливості, які визначаються стійко підвищеними рівнями високочутливого С-реактивного білка, незважаючи на адекватне зниження рівня холестерину ліпопротеїдів низької щільності [12].

4. Інші протизапальні терапевтичні підходи за КМР

Щодо інших підходів, спрямованих на усунення запалення як патогенетичного чинника за серцево-судинних захворювань атеросклеротичного походження, то сьогодні їх інтенсивно досліджують. Установлено, що збільшення кількості макрофагів й інших імунних клітин у жировій тканині, яке супроводжує розвиток ожиріння у гризунів і людини, може бути причетним до локального запалення або системної інсулінорезистентності, пов'язаної 3 ожирінням. Зменшення лейкоцитарної інфільтрації адипоцитів послаблює запальну реакцію і потенціально покращує чутливість жирової тканини до інсуліну. Сьогодні хемоатрактанти, зокрема лейкотрієни (за структурою ліпіди) та хемокіни (за структурою поліпептиди), являють собою додаткову ціль для протизапальних втручань за КМР.

Лейкотрієни (ЛТ) являють собою високопотужні хемоатрактанти, які утворюються в ділянках пошкодження й запалення, де скупчуються нейтрофіли або інші мієлоїдні клітини. Біосинтез ЛТ відбувається через конверсію арахідонової кислоти. Спочатку під впливом 5-ліпооксигенази (5-ЛО) і 5-ліпооксигеназактивуючого протеїну (5-ЛОАП) утворюється ЛТА4. Потім під впливом ЛТА4гідролази він перетворюється у високоактивний ЛТВ4 або за участі ЛТС4-синтази утворюються цистеїнові ЛТС4 та D4. Лейкотрієн B4 сполучається із сигнальним рецептором 1-го типу для лейкотрієнів В (ВЛТ1), а цистеїнові ЛТС4 та ЛТD4 - із цистеїновими лейко- 
трієновими рецепторами 1-го і 2-го підтипів. Сьогодні тривають дослідження по вивченню впливу антагоністів ферментів, що залучаються в біосинтез ЛТ (5-ЛО, 5-ЛОАП, ЛТА4-гідролаза), а також антагоністів рецепторів ВЛТ1 на наслідки КМР.

Аналогічно розрив взаємодії цитокінів із відповідними рецепторами може опинитись корисним в усуненні індукованих ожирінням інсулінорезистентності та запалення, однак такому підходу суттєво перешкоджає надлишок хемокінів і хемокінових рецепторів. У експериментальних дослідженнях із відтвореними КМР вивчали вплив розриву взаємодії цитокіна CCL2 з відповідним рецептором CCR2 на скупчення моноцитів у ділянках запалення. Про результати клінічних досліджень 3 антагоністами CCR2 повідомлень немає. Терапевтичний цільовий підхід із пригніченням циклооксигенази-2, що досліджували в експерименті на щурах, яких годували фруктозою, може бути корисним у зменшенні запалення в жировій тканині та покращанні ії чутливості до інсуліну. Однак у клінічній практиці застосування інгібіторів циклооксигенази-2, як відомо, асоціюється з підвищенням кардіоваскулярного ризику, що може бути вагомим обмеженням для такого підходу. Новітніми терапевтичними підходами до впливу на запалення при КМР є оцінювання ефективності протизапальних дієт $[13,14]$ та модуляція індивідуальної мікробіоти [15].

\section{Висновки}

Зумовлене ожирінням хронічне запалення асоціюється з цукровим діабетом 2-го типу й серцево-судинними захворюваннями атеросклеротичного генезу. За цих коморбідних станів воно виступає в ролі патологічного медіатору. Результати постійно зростаючої кількості експериментальних і клінічних досліджень підтверджують запальну гіпотезу, але в клінічних дослідженнях пошук терапевтичних втручань у запалення як мішень для лікування або профілактики кардіометаболічних розладів досі триває. Існує багато патогенетичних сигнальних механізмів, які ініціюють і підтримують, залучаючи його в формування інсулінорезистентності й атерогенез. Фармакологічні підходи до сучасного лікування хворих на цукровий діабет передбачають використання лікарських засобів, що справляють безпосередній або опосередкований протизапальний ефект, при цьому останній може робити повний внесок у покращання метаболічного статусу. I, навпаки, деякі протизапальні втручання можуть погіршувати вуглеводний обмін і кардіоваскулярне здоров'я. Сьогодні за результатами клінічних досліджень ми можемо припустити, що цільове фармакологічне втручання навіть в одну ланку запального каскаду може по-різному впливати на дисглікемію й атерогенез. Поглиблене розуміння біологічних процесів, що лежать в основі запальних реакцій, допоможе в розробці комплексу безпечних і ефективних терапевтичних втручань, здатних знизити кардіоваскулярний ризик, оскільки одного втручання може бути недостатньо для оптимального лікування пацієнтів із патологічними станами, пов'язаними з метаболічними розладами й атеросклерозом.

\section{Список літератури}

1. Рябуха B. В. Хронічне запалення, асоційоване з ожирінням, цукровим діабетом 2-го типу та кардіоваскулярним ризиком, як мішень для терапевтичних втручань. Частина 1 / В. В. Рябуха // Медицина сьогодні і завтра. - 2018. - № 4 (81). - С. 44-50.

Riabukha V.V. (2018). Khronichne zapalennia, asotsiiovane z ozhyrinniam, tsukrovym diabetom 2-ho typu ta kardiovaskuliarnym ryzykom, yak mishen dlia terapevtychnykh vtruchan. Chastyna 1 [Chronic inflammation associated with obesity, diabetes mellitus type 2 and cardiovascular risk as a target for therapeutic interventions. Part 1]. Medytsyna sohodni i zavtra-Medicine Today and Tomorrow, vol. 81, № 4, pp. 44-50 [in Ukrainian].

2. Nohria A., Kinlay S., Buck J.S., Redline W., Copeland-Halperin R., Kim S., Beckman J.A. (2014). The effect of salsalate therapy on endothelial function in a broad range of subjects. J. Amer. Heart Assoc., vol. 3, № 1, e000609.

3. Hauser T.H., Salastekar N., Schaefer E.J., Desai T., Fowler K.M., Weber G.M. et al. (2016). Effect of targeting inflammation with salsalate: The TINSAL-CVD randomized clinical trial on progression of coronary plaque in overweight and obese patients using statins. JAMA Cardiol., vol. 1, № 4, pp. 413423. 
4. Penesova A., Koska J., Ortega E., Bunt J.C., Bogardus C., de Courten B. (2015). Salsalate has no effect on insulin secretion but decreases insulin clearance: a randomized, placebo-controlled trial in subjects without diabetes. Diabetes Obese Metab., vol. 17, № 6, pp. 608-612.

5. Goldfine A.B., Shoelson S.E. (2017). Therapeutic approaches targeting inflammation for diabetes and associated cardiovascular risk. J. Clin. Invest., vol. 127, № 1, pp. 83-93.

6. Pirkmajer S., Kulkami C.P., Tom R.Z., Ross F.A., Hawley S.A., Hardie D.G. et al. (2015). Methotrexate promotes glucose uptake and lipid oxidation in skeletal muscle via AMPK activation. Diabetes, vol. 64, № 2, pp. 360-369.

7. Rotte M.C., de Jong P.H., den Boer E., Pluijm S.M., Ozean B., Weel A.E. et al. (2014). Effect of methotrexate use and erythrocyte methotrexate polyglutamate on glycosylated hemoglobin in rheumatoid arthritis. Arthritis Rheumatol., vol. 66, № 8, pp. 2026-2036.

8. Dinarello C.A., van der Meer J.W. (2013). Treating inflammation by blocking interleukin-1 in humans. Semin. Immunol., vol. 25, № 6, pp. 469-484.

9. Van Popper P.C.M., Van Asseldonk E.V.A., Netea M.G., Tack C.J. (2013). The interleukin-1 receptor antagonist anakinra improves beta cell function in subjects with impaired glucose tolerance. Proceeding from $49^{\text {th }}$ Annual Meeting of the European Association for the Study of Diabetes, abstract 739.

10. Cavelti-Weder C., Babians-Bruner A., Keller C., Stahel M.A., Kurz-Levin M., Zayed H. et al. (2012). Effects of gevokizumab on glycemia and inflammatory markers in type 2 diabetes. Diabetes Care, vol. 35, № 8, pp. 1654-1662.

11. Sloan-Lancaster J., Abu Raddad E., Polzer J., Miller J.W., Scherer J.C., De Gactano A. et al. (2013). Double-blind, randomized study evaluating the glycemic and anti-inflammatory effects of subcutaneous LY2189102, a neutralizing IL- $1 \beta$ antibody, in patients with type 2 diabetes. Diabetes Care, vol. 36, № 8, pp. 2239-2246.

12. Ridker P.M., Howard C.P., Walter V., Everett B., Libbi P., Hensen J., Thuren T.; CANTOS Pilot Investigative Group. (2012). Effects of interleukin-1 $\beta$ inhibition with canakinumab on hemoglobin A1c, lipids, C-reactive protein, interleukin-6, and fibrinogen: a phase IIb randomized, placebo-controlled trial. Circulation, vol. 126, № 23, pp. 2739-2748.

13. Graffouillere L., Deschasaux M., Mariotti F., Neufcourt L., Shippava N., Hebert J.R. et al. (2016). Prospective association between the Dietary Inflammatory Index and mortality: modulation by antioxidant supplementation in the SU.VI.MAX randomized controlled trial. Am. J. Clin. Nutr., vol. 103, № 3, pp. $878-885$.

14. Ruiz-Canela M., Bes-Rastrollo M., Martinez-Gonzalez M.A. (2016). The role of dietary inflammatory index in cardiovascular disease, metabolic syndrome and mortality. Int. J. Mol. Sci., vol. 17, № 8, pii E1265, DOI 10.3390/ijms17081265.

15. Utzschneider K.M., Kratz M., Damman C.J., Hullarg M. (2016). Mechanisms linking the gut microbiome and glucose metabolism. J. Clin. Endocrinol. Metab., vol. 101, № 4, pp. 1445-1454.

\section{B.B. Рябуха ХРОНИЧЕСКОЕ ВОСПАЛЕНИЕ, АССОЦИИРОВАННОЕ С ОЖИРЕНИЕМ, САХАРНЫМ ДИАБЕТОМ 2-ГО ТИПА И КАРДИОВАСКУЛЯРНЫМ РИСКОМ, КАК МИШЕНЬ ДЛЯ ТЕРАПЕВТИЧЕСКИХ ВМЕШАТЕЛЬСТВ. ЧАСТЬ 2}

Обзор литературы посвящен актуальной исследовательской проблеме - хроническому воспалению, ассоциированному с ожирением, сахарным диабетом 2-го типа и кардиоваскулярным риском. Поскольку воспаление выступает в роли патологического медиатора при этих коморбидных состояниях, делаются попытки повлиять на хронический воспалительный процесс с помощью лекарственных средств для снижения риска возникновения сердечно-сосудистых заболеваний атеросклеротического генеза. Это связано с патогенетическими сигнальными механизмами, инициирующими и поддерживающими воспаление, а также вовлекающими его в развитие инсулинорезистентности и атерогенез. Рассмотрены способы фармакологических вмешательств с непосредственным воздействием на воспаление (салицилаты, низкодозовое применение метотрексата, биологические препараты с противовоспалительным действием) и другие лечебные мероприятия с противовоспалительным эффектом (антилейкотриеновая терапия) в контексте их влияния на кардиометаболический риск.

Ключевые слова: кардиометаболические нарушения, воспаление, лекарственные средства. 


\section{V.V. Riabukha \\ CHRONIC INFLAMMATION ASOCIATED WITH OBESITY, DIABETES MELLITUS TYPE 2 \\ AND CARDIOVASCULAR RISK AS A TARGET FOR THERAPEUTIC INTERVENTIONS. PART 2}

The review is devoted to an actual research problem such as a chronic inflammation associated with obesity, diabetes mellitus type 2 and cardiovascular risk. As far as inflammation plays a role of pathologic mediator in these comorbid states, there are several attempts to influence on a chronic inflammatory process with medications for reduction of cardiovascular atherosclerotic disease risk are being done. It is related to some pathogenic signal mechanisms initiated and supported inflammation as well as involved it to the development of insulin resistance and atherogenesis. Methods of pharmacological interventions with a directly target inflammation (salicylates, low-dose methotrexate, anti-inflammatory drugs) and other therapeutic measures with an anti-inflammatory effect (antileukotriene therapy) in the context of their effect on cardiometabolic risk are considered.

Keywords: cardiometabolic disorders, inflammation, medications.

Надійшла 10.12 .18

\section{Відомості про автора}

Рябуха Владислав Валерійович - кандидат медичних наук, старший науковий співробітник відділу ішемічної хвороби серця та метаболічних порушень ДУ «Національний інститут терапії ім. Л.Т. Малої НАМН України».

Адреса: 61039, м. Харків, пр. Любові Малої, 2а, ДУ «Національний інститут терапії ім. Л.Т. Малої НАМН України».

Тел.: +38(057)770-15-38.

E-mail: dr_vl@ukr.net.

ORCID: https://orcid.org/0000-0002-1850-1845. 